\title{
THE EFFECTIVENESS COMPARISON BETWEEN INQUIRY AND PROBLEM BASED LEARNING TOWARDS GEOGRAPHY LEARNING OUTCOMES
}

\author{
Upang Septa Putra $^{1 *}$ and Muhsinatun Siasah Masruri ${ }^{1}$ \\ ${ }^{1}$ Master Program of Geography Education, Yogyakarta State University, Indonesia \\ *Email : upangsepta94@gmail.com
}

Received 5 May 2019/ Revised 5 July 2019/ Accepted 16 July 2019/ Published 20 August 2019

\begin{abstract}
This study aims to determine the differences of learning outcomes between students that were performed using inquiry and student who were applied using problem based learning in classes of X SMA 2 Plakat Tinggi. This study also purposes to examine the effectiveness comparison between problem based learning and inquiry method. The research engages quantitative research with quasi-experimental type. Subject selection conducts match design. The population of this study were students of class X IPS in SMA 2 Plakat Tinggi which composed of three classes. The sample selection in this study engaged purposive sampling, hereby X IPS 3 was elected as experimental group 1 (Problem based learning) and class X IPS 1 as the experimental group 2 (Inquiry) class. Data collection technique performed in this study was learning outcomes in the form of written test. Data analysis technique was engaging independent sample t-test, which was followed by $\mathrm{N}$ increased and effect size extent. The findings are differences of learning outcomes improvement between students who studied utilizing inquiry method and students who were taught using problem based learning method. Problem based learning is more effective than inquiry in promoting Geography learning outcomes. This is indicated through calculation result upon effect size extent, where students who were taught using problem based learning method obtain a value of 4.185 , larger compared to those who were treated using inquiry method which obtain a value of 3.462 .
\end{abstract}

Keywords: Inquiry, Problem Based Learning, Geography

\section{Introduction}

The rapid development in the sense of education is increasingly improved and this developing condition requires students capacity in mastering comprehensive the subjects matter of school, especially on geography subject. Since, within geography subject students are not only provided the content in the form of theory, but also directly examine geographycontent on daily basis. Sumaatmadja (2001: 12) argues that geography learning is 
essentially an image of spatial aspects of the earth surface, which is the whole symptom of nature and human life upon regional variations. In addition, during geography learning students are compulsory to investigate all human activities that are closely related to the surrounding environment, namely: atmosphere, lithosphere, hydrosphere and biosphere. The presence of geography learning is expected to establish and develop students understanding of variation and spatial organization between communities within residence and the environment on earth surface. Geography obtains original features, namely thinking process, in which geography examines things or symptoms that have interdependent relationships between one symptom to another. Futhermore, there is geographical manner of thinking which needs an analysis of a concrete object relationship and symptoms, whose spatial relations can be captured by the five senses.

However, students were not adequately interested in geography learning, since students considered geography subject as unattractive subject which was determined through observations conducted at SMA 2 Plakat Tinggi. When the learning process occured in the classroom, students have not been actively involved in the learning process. This fact could be observe daccording to students participation during the learning process which tended to be insufficient and passive. For instance, when teacher presented questions to students, there were only one or two students who were able to complete the answers. Students behavior who have not been actively involved in geography subjects was certainly determined by several factors, both internal and external. Internal factors are namely; student attitudes toward learning which was tend to be conventional, as well as insufficient interest and motivation. While external factors, for example, were related to the application of learning methods that were monotonous. Most learning methods engaged at SMA 2 are conventional namely coursework/lecture method and assignment completion. Hence, during learning process students were basically uniterested and became bored quickly.

Inorder to cope all the issues, teacher must be able to arrange, design and implement effective and efficient learning. Thus, it is expected to enhance students motivated during learning process and improve learning outcomes as well. Futhermore, in order to provide students learning motivation, of course an appropriate learning method is required. Learning method is a method engaged to implement plans that have been prepared, in the form of real and practical activities to achieve the learning objectives referring Suprijono (2015: 50). Utilizing suitable learning method could generate easier manner for students to understand geographic subjects that will affect improvement of student learning outcomes. There are several learning methods that can be engaged towards geography learning process namely; 
inquiry-based learning methods, discovery-based learning (discovery), problem-based learning (problem based learning), and project-based learning (project based learning). However, considering all the method provided, there are two the most appropriate methods to be utilizied, namely inquiry based learning and problem based learning. Utilizing both methods allowing students more convenience to embrace thecontents that is directly related to the real life, including the symptom or phenomena and problems that prevails in daily life and capable in improving the value of optimal learning outcomes.

Alberta (2004: 1) mentions during Inquiry based learning processes students are participating on to learning, formulate questions, learn comprehensively and then build new understandings, meanings and knowledge. This assumption can be interpreted that Inquiry Based Learning (IBL) is a learning process where students are involved within formulating questions that lead to conduct investigations in an effort to construct new knowledge and meanings. Inquiry process is a stage of promoting problems, obtaining information, thinking creatively in possible solutions, making decisions and arranging conclusions based existing problems. In contrary, compared to what was stated earlier, Duran \& Dokme (2016: 2889) convinced that Inquiry based learning can be defined as a learning approach in encouraging students to be active throughout the learning process, enhancing their scientific processsuitable to skills, and improving critical-thinking skills through discussions and activities. This statement is strongly associate towards opinion expressed by Unver \& Sertac (2011: 304) argues that inquiry based learning is a learning activity that refers to student activities, where students allow to develop knowledge and understanding of scientific ideas, as well as understanding how scientists figure out about the world. Increasing knowledge and understanding as well as scientific ideas gained by students, especially for subjects which are expected to improve geography learning outcomes.

Inquiry based learning explanation above relates to Mundilarto's research (2013: 256) which concludes that inquiry approach is more effective in improving student learning outcomes compared to the conventional approaches. Basically, inquiry method characteristics according to Smith \& Walker (2010: 27) are; (a) learning is stimulated by inquiry, it is established by questions or problems, (b) learning is based on a process of constructing knowledge and new insight, (c) an active approach to learning, involves learning by doing, a student-centered approach to teaching in which the role of the teacher is a facilitator (d) anaction to self-directed learning which students are performing high responsibility upon their learning. Inquiry method learning stages according to Blessinger \& John (2014: 11) are: 
exploration, problem identification, investigation, data collection and analysis, conclusions formulation obtained based on creative communication result.

Inquiry learning is different compared to Problem based learning (PBL). According to Simone (2014: 18), Problem Based Learning is a pedagogical approach centered on learners, whichconveys students the opportunity to engage into investigations directed towardslearning subjectives. This definition is supported by Yew \& Karen's result (2016: 2) that Problembased learning is a pedagogical approach that enables students to learn while engaging actively with problems, this is different towards previously stated, Whitcombe (2013: 41) convinces that problem-based method learning attempts students the opportunity to develop skills, such as problem solving, clinical reasoning, and assist students with skills to acquire science/knowledge. Regarding students skills when solving a problem, reasoning and debriefing are obtained through stages of problem-based learning method. These stages are expected to facilitate students to acquire new knowledge in order to achieve optimal learning outcomes. This matter associates towards Agustini's research results (2017: 97-98) which state PBL promotes students directly in learning to dissemninate knowledge through real visualization. Thereby, PBL enables improvement ofstudents learning outcomes. Students during learning process within Problem based learning are actively involved in preparing and communicating opinions. Overall, students attitudes engaging PBL method can be consideredas active and interested in the learning process. PBL does not only improve student learning, but increases student learning outcomes

Problem based learning method characteristics according to Barrett \& Moore (2010: 94-95) are: (a) the issue/problem presented must obtain more than one solution, (b) the problem must be complex, (c) the problem must be structured reasonably, (d) problem must be multidisciplinary, (e) problem concerns on teamwork, (f) problems must require ideas in problem solving, (g) problem solving requires source references, (h) problems require identification in the process learning, (i) each student or group must reflect the effectiveness of the learning solution. While, problem based learning stages according to Seng (2009: 9), are featuring 5 steps as follows: (a) identifying the problem, (b) problem analyzing and learning issues formulating, (c) discovering and reporting, (d) presenting solution and reflecting, (e) and ovierview, integrating and evaluating. Contrary tothe Seng's, Yuniwati (2016: 17) explains the steps of problem-based learning namely: (a) identifying a problem and examining relevant information sources, (b) independent learning (self directed learning), (c) investigating a problem and performing interpretation, (d) establishing several alternative 
solutions to problems (high cognitive complexity), (e) integrating opinions or information data to determine problems solution, and (f) self reflecting.

\section{The Methods}

The research method used is a scientific approach to obtain data with specific objectives and uses. Relating the research that would be conducted, this research is a quantitative type with a quasi-experimental approach using Match Subject Design. Research population were students of class X IPS of SMA 2 Plakat Tinggi which composed of 3 classes. Then, researcher collected a sample employing a purposive sampling. Hence, the sample selected was Class X IPS 3of 35 students as an experimental class with problem based learning method and Classes X IPS 1 as an experimental class using inquiry method which composedof 33 students. The data collection technique employed in this study was learning outcome in term of geography learning test with 20 multiple choice questions. The test was engaged to determine general ability before and after treatment provided.

Data analysis technique engaged within this research obtained two stages, namely data description stage and the hypothesis testing stage. The action performed upon data description test stage was formulating a summary of data distribution in the form of prettest and posttest using the SPSS 20.00 for window. While for hypothesis examination was performing independent sample t-test. Data analysis regarding geography learning outcomes improvement was conducted by the $\mathrm{N}$ gain score. $\mathrm{N}$ gain score is obtained through posttest results calculation which are reduced by the prettest value in experimental classes performed inquiry and problem based learning. In calculating the $\mathrm{N}$ gain formula, researcher utilized the following formula:

$$
\mathrm{N} \text { gain }=\frac{\text { FinalScore }- \text { Initial Scors }}{\text { Initial } \text { test } \text { Score }} \times 100 \%
$$

Then, assessing the effectiveness of the learning method is performing by calculating the effect size (ES). The formula used according to Warner (2008: 202) is as follows:

$$
\mathrm{D}=\frac{M 2-M 1}{S}
$$

Information:

$\mathrm{EZ}=$ Effect Size

M1 = Prettest Mean 
M2 $=$ Posttest Mean

$\mathrm{SP}=$ Standard posttest deviation

The calculation results obtained from calculations formulated through over effect size are categorized toward criteria proposed by Cohen (1988) about the level of the effect size as follows: Ice $\leq 0.2$ (Low), $0.2 \leq$ Es $\leq 0.8$ (Moderate), and Ice $\geq 0.8$ (Height).

\section{Results and Discussion}

This research is quantitative one that applying two classes as experimental classes. Learning outcomes were acquired based on two times tests, namely pretest and posttest. Pretest was performed to determine thestudents initial abilities (pretest) and the final test (posttest) used to determine the ability of students after being treated with certain learning methods.

3.1 Pretest Results of Experimental Classes Engaging Inquiry and Problem Based Learning

Description of the prettest results of student learning outcomes can be seen in table 1 as follows:

Table 1. Description of Prettest Data of Student Geography Learning Outcomes

\begin{tabular}{clcc}
\hline No & \multicolumn{1}{c}{$\begin{array}{c}\text { Descriptive Statistics } \\
\text { Results }\end{array}$} & Inquiry & Problem based learning \\
\hline 1 & Mean & 44.24 & 46.42 \\
2 & Mode & 40 & 40 \\
3 & Median & 45 & 45 \\
4 & Deviation Standard & 8.20 & 9.43 \\
\hline
\end{tabular}

Source: Primary data processing (2018)

Based on the table, it shows that the average prettest value of students in the experimental group 1 applied using the problem based learning method obtain an average value of 46.42, mode 40 , median 45 and a standard deviation of 9.43. While the average prettest value of students in the experimental group 2 applied using the inquiry method obtain an average value of 44.24, mode 40, median 45 and a standard deviation of 8.20 .

3.2 Posttest Results of Experimental Classes Engaging Inquiry and Problem Based Learning 
Description of prettest data results of students learning can be seen in table 2 as follows:

Table 2. Description of Posttest Data of Student Geography Learning Outcomes

\begin{tabular}{clcc}
\hline No & \multicolumn{1}{c}{ Descriptive Statistics } & Inquiry & Problem based learning \\
\hline 1 & Mean & 82.00 & 75.00 \\
2 & Mode & 80 & 75 \\
3 & Median & 80 & 75 \\
4 & Standard Deviation & 8.50 & 9.10 \\
\hline
\end{tabular}

Source: Primary data processing (2018)

Based on the table, it shows that the average posttest value of students in experimental group 1 applied using the problem based learning method obtain an average value of 82.00 , mode 80 , median 85 and standard deviation of 8.50. While, the average posttest value of students in the experimental group 2 applied using the inquiry method obtain an average value of 75.00, mode 75 , median 75 and a standard deviation of 9.10 .

3.3 Comparison of Average Prettest, Posttest and N Gain results of Geography Learning Outcomes

Student learning outcomes escalation in experimental class engaging inquiry method and problem based learning method is recognizable with comparison between prettest and posttest values figured in the gain score. Based on the calculation of gain score obtain the average value of increasing student learning outcomes of experimental class treated with inquiry method is 31.51. Students learning outcomes who were performed problem based learning have increased by 35.58 . The gain score results of experimental class based inquiry method and problem based learning presented in table 3 below:

Table 3. Comparison of average Prettest, Posttest and N Gain results of Geography learning outcomes

\begin{tabular}{clccc}
\hline No & Learning Methods & Prettest & Posttest & N Gain \\
\hline 1 & Inquiry & 43.18 & 74.69 & 31.51 \\
2 & Problem based learning & 46.42 & 82.00 & 35.58 \\
\hline
\end{tabular}

Source: Primary data processing (2018) 
Based on it table 3, it could be examined the differences of learning outcomes improvement of geography between inquiry and problem based learning within two groups. Experimental group treated using inquiry method experience an incline of learning outcomes by 31.51 , while the learning outcomes applying problem based learning method increases by 35.58 .

\subsection{First Hypothesis Examination}

Table 4. Statistics Test of Student Learning Outcomes using Independent Samples Test

\begin{tabular}{cccccc}
\hline & & \multicolumn{4}{c}{ t-test for Equality of Means } \\
& $\mathrm{T}$ & $\mathrm{df}$ & $\begin{array}{c}\text { Sig. }(2- \\
\text { tailed) }\end{array}$ & $\begin{array}{c}\text { Mean } \\
\text { Difference }\end{array}$ \\
\hline $\begin{array}{c}\text { Geography } \\
\text { learning } \\
\text { results }\end{array}$ & $\begin{array}{c}\text { Equal variances } \\
\text { assumed } \\
\text { Equal variances } \\
\text { not assumed }\end{array}$ & -2.722 & 66 & $\mathbf{. 0 0 8}$ & -.10689 \\
\hline
\end{tabular}

\section{Sources: Statistical results based on SPSS 22.00}

Based on the results of variance analysis calculation relating the differences of achievement upon learning outcomes between students who performed problem based learning and inquiry method with errors opportunity of (p) 0.008 , it is smaller than the specified level of significance of 0.05 . The output results assisted with SPSS 22.00 application presented in the table. It can be concluded that the value of $t$ is equal to $-2,722$ with $\mathrm{p}$ value smaller than alpha 0.05 . Then $\mathrm{HO}$ is rejected and $\mathrm{Ha}$ is accepted.

According to these results, it can be revealed that the null hypothesis (H0) is rejected. This means "there is a significant difference of learning outcomes intensification between students who using problem based learning method and students who learned using the inquiry method". Gain score value based on calculation results between a class applied with inquiry learning and a class with problem based learning method, the percentage of the Gain score in table 5 is obtained as follows: 
Table 5. Percentage of Gain Score

\begin{tabular}{cccc}
\hline No & Learning Methods & Test & Result Score \\
\hline \multirow{3}{*}{1} & Inquiry & Prettest Average & 43.18 \\
& & Posttest average & 74.69 \\
& Gain Score & 31.51 \\
& \% Gain Score & 71.13 \\
& \multirow{3}{*}{ Problem based learning } & Prettest Average & 46.42 \\
& & Posttest average & 82.00 \\
& & Gain Score & 35.58 \\
& & \% Gain Score & 76.61 \\
\hline
\end{tabular}

Source: Primary data processing (2018)

Based on the table, the gain percentage score of learning outcomes in class applied with the inquiry method is 71.13 , smaller than the class applied engaging problem based learning which is 76.61. Considering these data, it could be assumed that achievement upon students learning outcomes between the class applied with inquiry method and another class applied with the problem based learning method has notable differences. The two classes engaged both inquiry method and Problem based learning have different learning outcomes, both pretest and posttest scores. The improvement highlight particularly emerges between posttest value and the pretest (Gain Score), there are prominent differences in learning outcomes $(76.71>71.13)$.

Based on the study results generated, it is obvious that problem based learning enables to promote students social studies learning outcomes, since problem based learning method is an actual method and suitable within activities carried out by students in their daily lives. Problem based learning method defines learning process that starts from initial stage of learning based on a problem occurs in real life. Then referring to the problem, students are stimulated to examine them based on knowledge and experience they obtain previously. Thereby, a new knowledge and experience will possibly formed. 


\subsection{Second Hypothesis Test}

Table 6. Effect Size Value of Inquiry and Problem Based Learning

\begin{tabular}{lccc}
\hline No $\quad$ Learning Methods & Test & Result Score \\
\hline & & Prettest Average & 43.18 \\
& Posttest average & 74.69 \\
& Inquiry & Gain Score & 31.51 \\
& Deviation Standard & 9.10 \\
& Effect Size & 3.462 \\
& Prettest Average & 46.42 \\
& Problem based learning & Gain Score & 32.00 \\
& & Deviation Standard & 8.50 \\
& & Effect Size & 4.185
\end{tabular}

Source: Primary data processing (2018)

Based on the table, it can be seen that the value of the effect size on inquiry method earns a value of 3.462 which is categorized as the high category. This value is persistent towards the effect size value on problem based learning method, which also gains 4,185 , that is classified as high category. According to these values, it can be concluded that problem based learning method engagement is more effective than inquiry method in term of students geographic learning outcomes of SMA Plakat Tinggi 2.

According to independent sample t-Test result analysis, it shows that there are slightly differences of Geography learning outcomes between students who were applied inquiry method over students who were applied problem based learning method. Results of this study indicate that geography subject utilizing problem based learning method is more adequate than inquiry method. Referring to students learning outcomes, presenting that student who were applied problem based learning method pose higher score than students who were performed using inquiry method. This achievement gained from statistical analysis, which is $p=0.008$, smaller than the specified level of 0.05 , which means significant. This result confirms that student learning outcomes based inquiry method obtain an average value of learning outcomes of 31.51, smaller comparedto problem based learning method which pose an average value of 35.58 .

Theoretically, Geography learning engages problem based learning method capable to motivate students in examining interesting problems and also challenges students to overcome a factualproblem occurs in everyday life. The similar statement is figured by 
Wijayanti \& Wulandari (2016: 119) who contends that learning process within problem based learning at the beginning stage of activity motivates students to solve interesting and also challenging problems. Hence, it would be more convienence for students to think at a higher level and get accustomed in solving the problems. Geography learning performs problem based learning method concerned on problems utilization reinforces students to relate problems encountered in daily life. Hence,students could interpret the learning material being delivered. Problem solving activities within early stage of learning process provide practices and insight for students to embrace new material. A problem that does not emphasize on procedures and algorithms help students to think independently in plan making and solving problems, evaluating solutions consequences and preparing other alternative solutions.

Problem based learning is deliberately designed in the form of problems, thus students enable to acquire new knowledge in order to promote students proficient in solving problems, capture their own learning strategies and skills to participate in teams. The learning process performs systemic approach to solve problems or challenges needed in everyday life. Futhermore, problem based learning method subjectives as follows: inaugurating flexible knowledge, developing effective problem solving skills that referring to the abilities to apply metacognitive strategies and appropriate reasoning, teachers must construct plans how learning process could achieve learning goals or not, teachers become good collaborators which, means participating effectively in small groups, assisting students to be intrinsically motivated, which usually occurs when students work on assignments for their own satisfaction, interests, or challenges (as cited in Bridges et al., 2012: 3). In addition, problem based learning application is expected that students could achievesignificant knowledge and able to boost geography learning outcomes.

Problem based learning and inquiry method occupy different features. Where problem based learning method ischaracterized of real life issues provided in daily lives of students. This is similar towards Handoyono (2016: 35) that inquiry method and problem based learning have characteristics upon problem given. In which, problem within inquiry method must be identified by students themselves, whereas within problem based learning, problems are determined by teacher. Thereby, problem based learning method utilization is purposed for students embracing more skills than memorizing, thinking skills, working with groups or solving problems. This is unquestionably different towards inquiry method based application that delivers assignments to students individually. Hence, students tend become more occupied in performing single task in a subject. In other words, inquiry method possibly derive students become frustrated once they are unable to complete a learning process. 
Based on the results of data analysis, it can be concluded that Geography learning applied with problem based learning method is more effective in improving student learning outcomes. This result reveals through calculations results using the effect size, while problem based learning method obtains 4,185, categorized as higher category. It is larger than inquiry method which has a value of 3,462 , that is categorized as high category. This also implies that students who performed problem based learning method have a posttest average value of 82.00 , higher than the results of the posttest inquiry method which obtain an average score of 74.69.

In general, according to McKeown et al. (2016: 2) explains that inquiry based learning is basically a question-based approach to teaching and learning that profitable for students in a number of ways including improvement and involvement in the learning process, understanding development, high-level thinking skills and research skills improvement. Contrary towards what was described earlier, Friesen \& David (2013: 21) state that Inquirybased teaching is a phenomenon that poses a challenging explanation of what they observe: devise and conduct experiments which data is collected to support or contradict their theories. Within learning process using inquiry method, students are actively involved in collaborating to create a new knowledge by thinking critically and creatively and can make good discoveries through investigation, reflection, exploration and experimentation. In addition, during inquiry method students are required to be responsible for their learning. After learning process is completed, the consequences could be observed based on learning outcomes improvement.

Characteristics of inquiry based learning stages referring to Minner et al. (2010: 476) are: (a) students are involved scientifically oriented questions, (b) students develop and evaluate every single learning outcome, (c) students allow to formulate and answer scientifically oriented questions, (d) students evaluate the problem explanation and provide alternative solutions, especially those related to scientific understanding. By engaging this indicator, makes it convenience to determine the learning process achievement extent received by students. While, the steps or syntax of inquiry-based learning process according to $\mathrm{Chu}$ et al. (2017: 136-138) are composed of opening, immersion, exploration, identification, searching, creating and evaluating, sharing, evaluation.

Goodman (2018: 255) argues that problem based learning is a teaching method that encourages students active learning. Basically, student work together to complete the problems. Thereby, students are required to perform research and solving complex issue. Problems presented of problem based learning method basically refer to contextual and 
authentic, that students encounter every day, whether in school or community environment. Thus,students are expected to provide opportunities and determine solutions upon real life problems. Problems determination upon problem based learning method have to be clear and meaningful. Then students may achieve optimal learning goals, optimal learning objectives occurs along with students learning outcomes enhancement. Problem based learning allows students to obtain new knowledge easier after arranging solutions towards daily life related problems.

The effectiveness of problem based learning method can be noticed from students ability in performing problem solving that has been provided. Thus, it is expected to promote students understanding the subject matter indaily life related problem. Problem based learning method requires students to be active within solving activities. Problem solving concept of PBL model is performed during group discussion. Problem based learning put strong emphasis on exchanging opinions and sharing experiences. Students who are highly motivated will be more interested in exploring knowledge and demanding to identify something new to solve problems related to the real world. Problem based learning method is expected to improve students' creative thinking abilities in Geography learning, which is based on real life problems that occur in daily life. Hence, learning process will likely be much more meaningful, since students are able to formulate answers and solve problems independently.

The problem provided in problem based learning is a problem related to daily life. Delivering problems inactual context aims to enable students to construct their own knowledge. This is associates to Trianto's argument (2010: 67) that problem-based learning presents authentic and impressive problem situations to students, so they could provide convenience manner to conduct investigations and inquiry. Through the problems given, students attempt to accomplish the problem based on students prior knowledge. Then, students will possible able to find relation between the previous contentto the new one which they are performing. Problems as the majorfocus of learning can be completed through team work. Thereby, students are able to perform diverse learning experiences such as collaboration and interaction in groups. In addition, learning experiences related to problem solving such as formulating hypotheses, designing experiments, conducting investigations, collecting data, interpreting data data, displaying conclusions, presenting, discussing, and writing reports Wijayanti \& Wulandari (2016: 121). This situation shows that problem based learning could implement more experience and knowledge compared to other learning methods. Furthermore, problem based learning method engagement allows students to 
increase their understanding of what they learn in everyday life and can be applied in contextual term.

The purposes of problem based learning method according to Hmelo-Silver (2004) are namely: constructing dynamic knowledge, developing effective problem solving skills that refer to the ability in applying metacognitive and reasoning strategies adequately, teacher ability to plan how the learning process can achieve learning goals, becoming good collaborators, which means participating effectively in small groups, supporting students to be intrinsically motivated, which occurs when students work on assignments for satisfaction, interest, or meet their own challenges (as cited in Bridges et al., 2012: 3). In addition, implementation of problem based learning method within learning process is expected students achievement in term of knowledge acquisition and learning outcomes escalation.

According to Grady et al.(2012: 150) propose problem based learning characteristics as follows: (a) lead to learning issues, (b) interest and stimulate triggers, (c) stimulate critical reasoning, (d) promote self directed learning, (e) related to prior knowledge and (f) promote teamwork. In addition, regarding previously characteristics of problem based learning method, the learning process begins with the following steps: (a) identify a problem and explore relevant information sources, (b) independent learning (c) conduct an investigation of a problem and interpret it, (d) prioritize several alternative solutions to problems (high cognitive complexity), (e) integrate opinions or information data to determine problems solutions, (f) self-reflection (Yuniawati, 2016: 17). Based on problem based learning method stages could derive a significant influence in improving student learning outcomes compared to inquiry method. Since, problem based learning method encourages students to recognize how to learn and cooperate in a group to determine a solution to the problems that prevails in the real world. Simulation stage are conducted to activate students curiousity before starting to learn a subject. In addition, the existence of this simulation prepares students to think critically and analytically, also to acquire and perform learning resources appropriately. It can be implied that problem based learning method is a learning process which has starting point of learning based on real life problems. Starts from this problem, students are stimulated to examine them according totheir knowledge and experience they had before hand. Thus, students new knowledge and experience will be formed. Discussion within small groups is the main point of problem based learning method implementation, as discussions would promote students exchange ideas or express opinions with each other. In addition, problem based learning method is a very effective guide in improving student learning outcomes, especially geography subject. 
As problem based learning (PBL) method poses many benefits compared to inquiry method, according to Westwood (2008: 31) PBL offers several reasons as follows: (a) encourage self-direction in learning, (b) prepare students for critical, analytical thinking, and empower students to identify, (c) finding and using appropriate resources, (d) the problems studied are closely related to the real world. Hence, it motivates students to learn, (e) promote students to be active in integrating information and skills from various scientific disciplines, knowledge and strategies tend to be restored and transferred to other learning situations, and improve the communication skills and social skills needed for teamwork and teamwork. In addition, problem based learning method poses a number of activities that must be completed for students, which expect students not only to record then memorize the subject matter, but also students are required to actively think, communicate, search and process data, and finally conclude. Referring to the two learning methods, both in the form of inquiry method and problem based learning method, as well as improving student learning outcomes, both of these learning methods are able to improve student learning outcomes of geographic subject. Where the calculation result of problem based learning enhances learning outcomes with average by 82.00 , higher than the average value of learning outcomes applied with inquiry method which obtains a value of 74.69

\section{Conclusion}

There is a difference significant difference of learning outcomes between students who learn engaging inquiry methods and problem-based learning methods. This can be observed based on average improvement in student learning outcomes between students who were treated with learning-based method gain value of 82.00 , higher than the average learning outcomes applied with inquiry method which obtains a value of 74.69. Problem-based learning method is more effectively applied to geography subjects rather than inquiry method in term of improving student learning outcomes. This is indicated by calculation results of effect size, which students who were performing problem based learning method obtain value of 4.185 , it is greater than the students who were applying inquiry method which obtain a value of 3.462 .

\section{References}

Agustini, D. M. (2017). PBL untuk Meningkatkan Hasil Belajar IPA Siswa Tunarungu Kelas IV A SLBN 2 Bantul. Widia Ortodidaktika, 6(4), 427-437. 
Alberta. (2004). Focus on Inquiry: A Teacher's Guide to Implementing Inquiry Based Learning. Canada: Learning Resources Centre.

Barret, T., \& Moore, S. (2010). New Approaches to: Problem based learning Reveitalising Your Practice in Higher Education. New York: Routledge.

Blessinger, P., \& Carfora, J. M. (Eds.). (2014). Inquiry-based learning for the arts, humanities and social sciences: A conceptual and practical resource for educators. Emerald Group Publishing.

Bridges, S., McGrath, C., \& Whitehill, T. L. (Eds.). (2012). Problem-based learning in clinical education: The next generation (Vol. 8). Springer Science \& Business Media.

Chu, S. K. W., Reynolds, R. B., Tavares, N. J., Notari, M., \& Lee, C. W. Y. (2017). 21st Century Skills Development Through Inquiry-Based Learning. doi:10.1007/978981-10-2481-8

Cohen J. (1988). Statistical Power Analysis for the Behavioral Sciences. New York, NY: Routledge Academic.

Duran, M., \& Dokme, L. (2016). The Effect of the Inquiry Based Learning Approach on Student's Critical Thinking Skills. Eurasia Journal of Mathematics, Science \& Technology Education, 12(12), 2887-2908. https://doi.org/10.12973/eurasia.2016.02311a.

Friesen, S., \& David, S. (2013). Inquiry Based Learning Review. Calgary: University of Calgary. Retrieved from https://www.researchgate.net/publication/312592892_Inquiry-

Based_Learning_A_Review_of_the_Research_Literature.

Goodman, D. (2018). Problem-Based Learning in the MPA Curiculum. Journal of Public Affrairs Education, 14(2), 253-270. Retrieved from http://www.jstor.org/stable/40215813.

Grady, G.O., Elaine H.J.Y., Karen, P.L.G., \& Henk, G.S. (2012).One Day One Problem an Approach to Problem Based Learning. Singapore: Springer.

Handoyono, N.A. (2016). Pengaruh Inquiry Learning Dan Problem-Based Learning terhadap Hasil Belajar PKKR Ditinjau dari Motivasi Belajar. Jurnal Pendidikan Vokasi, 6(1). http://dx.doi.org/10.21831/jpv.v6i1.8114.

Hmelo-Silver, C. E. (2004). Problem-based learning: What and how do students learn?. Educational psychology review, 16(3), 235-266.

McKeown, T. R., Abrams, L. M., Slattum, P. W., \& Kirk, S. V. (2015). Enhancing Teacher Beliefs through an Inquiry-Based Professional Development Program. Journal of Education in Science, Environment and Health, 2(1), 85. doi:10.21891/jeseh.30143 
Minner, D. D., Levy, A. J., \& Century, J. (2010). Inquiry-based science instruction-what is it and does it matter? Results from a research synthesis years 1984 to 2002. Journal of Research in Science Teaching, 47(4), 474-496. doi:10.1002/tea.20347

Mundilarto. (2013). Keefektifan Pembelajaran Inquiry Based Learning untuk Peningkatan Karakter Siswa pada Pembelajaran Fisika. Jurnal Cakrawala Pendidikan. Retrieved from https://journal.uny.ac.id/index.php/cp/article/download/1483/pdf.

Seng, T.O. (2009). Problem Based Learningand Creativty. Singapore: Cengage Learning Asia Pte Ltd.

Simone, C.D. (2014). Problem Based Learning in Teacher Education: Trajectories of Change. International Journal of Humanities and Social Science, 4(12).Retrieved from http://www.ijhssnet.com/journals/Vol_4_No_12_October_2014/3.pdf.

Smith, R.S., \& Walker, R. (2010). Can Inquiry-Based Learning Strengthen the Links between Teaching and Disciplinary Research? Studies in Higher Education, 35(6), 723-740. https://doi.org/10.1080/03075070903315502.

Sumaatmadja, N. (2001). Metode Pengajaran Geografi. Jakarta: BumiAksara.

Suprijono, A. (2015). Cooperative Learning Teori \& Aplikasi Paikem. Yogyakarta: Pustaka Pelajar

Trianto. (2010). Model Pembelajaran Terpadu: Konsep, Strategi, dan Implementasinya dalamKurikulum Tingkat Satuan Pendidikan (KTSP). Jakarta: Bumi Aksara.

Unver, A.O., \& Sertac, A. (2011).Ovierviews on Inquiry Based and Problem Based Learning Methods. Western Anatolia Journal of Educational Science, 303-309. Retrieved from http://webb.deu.edu.tr/baed/giris/baed/ozel_sayi/303-310.pdf.

Warner, R.M. (2008). Applied Statistic. USA: Sage Publications.

Westwood, P.S. (2008). What the Teacher Need to Know About Teaching Methods. Camberwell, V: Acer Press.

Whitcombe S.W. (2013) Problem-based Learning Students' Perceptions of Knowledge and Professional Identity: Occupational Therapists as 'Knowers', British Journal of Occupational Therapy,76(1), 37-42

Wijayanti, A., \& Wulandari, T. (2016). Efektivitas Model CTL dan Model PBL terhadap Hasil Belajar IPS. Harmoni Sosial: Jurnal Pendidikan IPS, 3(2), 112. doi:10.21831/hsjpi.v3i2.7908

Yew, E.H.J., \& Karen, G. (2016). Problem-Based Learning: An Overview of its Process and Impact on Learning. Journal Health Professions Education, 2(2), 75-79. https://doi.org/10.1016/j.hpe.2016.01.004l. 
Upang Septa Putra and Muhsinatun Siasah Masruri/ GEOSI Vol 4 No 2 (2019) 146-163

Yuniawati. (2016). Peningkatan Kualitas Pembelajaran PPKN Melalui Penerapan Problem Based Learning di SMP. Jurnal Pendidikan IPS. Retrieved from https://journal.uny.ac.id/index.php/hsjpi/article/view/7947/8576. 